\title{
STRENGTHENING THE NUCLEAR-REACTOR FUEL CYCLE AGAINST PROLIFERATION
}

\author{
by \\ Armando Travelli, James Snelgrove, Paul Persiani \\ Arms Control and Nonproliferation Program \\ Argonne National Laboratory \\ 9700 South Cass Avenue \\ Argonne, Illinois 60439
}

for
Verification Technologies Review

Third Quarter 1992

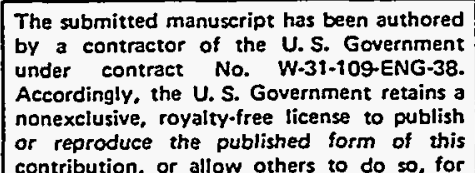

DISCLAIMER
This report was prepared as an account of work sponsored by an agency of the United States Government. Neither the United States Government nor any agency thereof, nor any of their employees, makes any warranty, express or implied, or assumes any legal liability or responsibility for the accuracy, completeness, or usefulness of any information, apparatus, product, or process disclosed, or represents that its use would not infringe privately owned rights. Reference herein to any specific commercial product, process, or service by trade name, trademark, manufacturer, or otherwise does not necessarily constitute or imply its endorsement, recommendation, or favoring by the United States Government or any agency thereof. The views and opinions of authors expressed herein do not necessarily state or reflect those of the United States Government or any agency thereof.
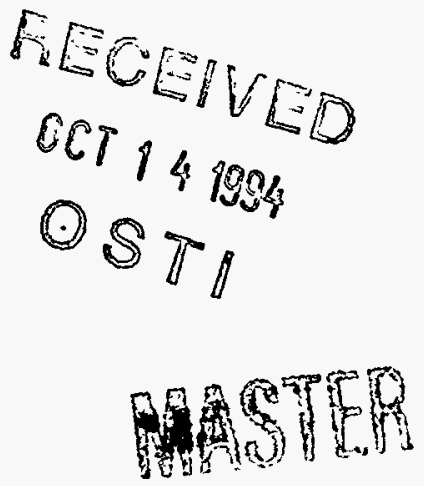


\section{DISCLAIMER}

Portions of this document may be illegible in electronic image products. Images are produced from the best available original document. 


\title{
STRENGTHENING THE NUCLEAR-REACTOR FUEL CYCLE AGAINST PROLIFERATION
}

\author{
by \\ Armando Travelli, James Snelgrove, Paul Persiani \\ Arms Control and Nonproliferation Program \\ Argonne National Laboratory
}

Argonne National Laboratory (ANL) conducts several research programs that serve to reduce the risks of fissile-material diversion from the nuclear-reactor fuel cycle. The objectives are to provide economical and efficient neutron or power generation with the minimum of inherent risks, and to further minimize risks by utilizing sophisticated techniques to detect attempts at material diversion. This paper will discuss the Reduced Enrichment Research and Test Reactor (RERTR) Program, the Isotope Correlation Technique (ICT), and Proliferation-Resistant Closed-Cycle Reactors. The first two are sponsored by the DOE Office of Arms Control and Nonproliferation.

\section{A. THE REDUCED ENRICHMENT RESEARCH AND TEST REACTOR PROGRAM}

Because of concern about the possible diversion from research and test reactors of highly enriched uranium (HEU) by nations, subnational groups, or terrorists the RERTR Program was started in 1977-78. At that time, HEU was used by over $50 \%$ of the world's research reactors, requiring annual exports from the U.S. of $\sim 600 \mathrm{~kg}$. When research reactors began to be exported from the U.S. under the Atoms for Peace program in the 1950 s, only fuel containing low-enrichment uranium (<20\%, LEU) was allowed. Subsequently, HEU became widely available, and many reactors began to use it without real need. Progress toward conversion of research reactors away from HEU is shown in Fig. 1.

The objective of the RERTR Program is to provide the technical means to reduce the enrichment of a reactor's fuel without compromising safety and without significant penalty in performance or economics. Significant progress toward this goal has been made by:

1. developing high-density fuels which will accommodate the extra ${ }^{238} U$ needed to reduce the enrichment. High-density fuels suitable to convert $90 \%$ of the existing research and test reactors have been developed, demonstrated, and qualified.

2. assisting in developing qualified fuel suppliers throughout the world. Five fuel fabricators are currently marketing LEU fuels, and another six are developing the capability. 
3. encouraging suppliers of research reactors to design and market only LEU-fueled reactors. All research reactors built or committed since 1980 have been designed for LEU cores.

4. encouraging and providing technical support to convert existing reactors to LEU fuel use. Twenty reactors in 19 countries are converting to LEU, five are irradiating or have irradiated LEU prototype elements, and 12 either are planning to convert or are believed to be technically capable of converting.

Currently, the RERTR Program is not actively developing the very-high-density fuels needed for the remaining few reactors that require considerable HEU exports; however, a proposal for such development has been submitted to DOE. Current activities are focussed on providing assistance to reactor operators. A proposal to expand the work to encompass the reactors of the former Soviet Union has been submitted to DOE.

\section{B. ISOTOPE CORRELATION TECHNIQUES}

Isotopic signatures (relative isotopic abundances) and correlation techniques (ICT) establish an independent means of validating declared information and monitoring operations of all types of facilities in the commercial power and nuclear weapons production cycles. The method of isotopic signatures detects anomalous operations in enrichment, fabrication, and reactor operations, and would disclose the production of undeclared nuclear materials in production and nonproduction facilities. For example, the removal and reprocessing of assemblies at low burnup to obtain weapons-grade nuclear material would be detected with the isotopic-correlation technique when other assemblies from that reactor loading were reprocessed. Similarly, the overloading of assemblies with target material (uranium or lithium) to increase nuclear material production would be detected from the reprocessing plant data on the isotopic signatures of the neighboring assemblies. The isotopic-correlation technique has been investigated for the potential to identify these uranium feed materials for use in enrichment processes. Isotopicseparation technologies and systems-analysis investigations of nuclear fuel cycles indicate that nonproliferation concerns should be emphasized at the front end of the fuel cycles involving low-enriched uranium (fresh fuel) as well as at the back end of those involving plutonium (spent fuel).

The isotope-correlation technique provides information relating to: the isotopics at enrichment facilities; the fabricators' uranium and plutonium isotopic content specifications; fabricators-output to reactor-input differences, in-situ reactor production and depletion of uranium and plutonium; reactor output and reprocessing plant input differences; and off-normal enrichment, reactor, and reprocessing operations, including measurement data anomalies (intentional or unintentional). Currently, the technique is being modified for country-specific implementation to validate declared information and monitor confirmed operations of facilities under potential arms-control agreements. 
The isotope correlation technique has been applied to some domestic and international fuel-cycle operations involving many classes of reactor systems (light-water, heavy-water, graphite, and liquid metal reactors) operating in a variety of modes (power, research, production, and breeder). A proposal has been submitted to expand the implementation to several country-specific fuel cycles. The isotopic signatures method could generate analogous information from isotopic measurements made on atmospheric and terrestrial environmental samplings of all types of facilities and of different natural and anthropogenic sources of nuclear matter.

\section{CLOSED-CYCLE REACTORS}

The transport and handling of fissile materials required to fuel power reactors can be strengthened against possible diversion by closing the fuel cycle at a single site. Fresh uranium would be shipped into the site and radioactive waste would be shipped out. Spent fuel with plutonium generated in the reactors would be reconsitituted on site and new fuel rods fabricated for the reactors.

Key assay points could be subject to safeguards, with provisions made to ease the measurement task. The isotope-correlation technique could be used to augment the assay. Because of the high radiation levels experienced in the reprocessing stream, fissile-assay techniques that are relatively insensitive to high gamma-fields must be employed, such as delayed-neutron and neutron-coincidence methods.

Argonne has been funded by DOE to establish and demonstrate an integral fast reactor using the closed-cycle concept. 
Fig.1 PROGRESS TOWARD CONVERSION OF RESEARCH REACTORS REQUIRING HEU EXPORTS

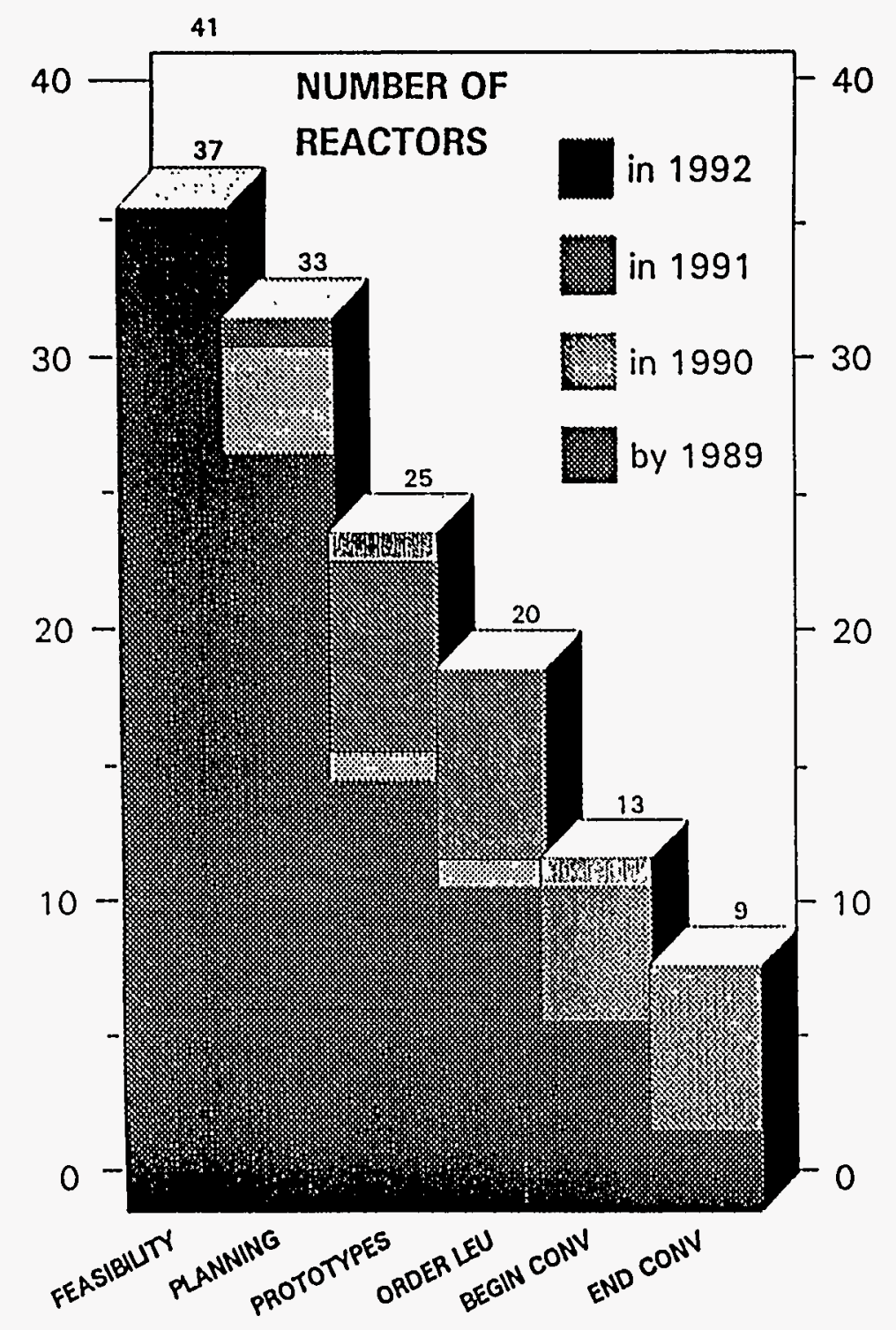

CONVERSION STEP REACHED



